\title{
Geographical Indications and quality promotion of agricultural products in Vietnam: an analysis of government roles
}

\author{
Nguyen Thu Thuy \\ Foreign Trade University (FTU), Vietnam \\ thuy.nt@ftu.edu.vn
}

Geographical indications (Gls) play an important in the agriculture sector; however, the link between geographical indications and quality promotion has not been adequately analysed. This paper aims to investigate the influences of geographical indications on the quality of agricultural products in Vietnam, considering the role of public policies in this matter. We review the literature in Gl protection in Vietnam, focusing on the role of the Government in structuring and implementing Gls and putting forward the institutional involvement. Three case studies on Phu Quoc fish sauce, Luc Ngan lychee and Moc Chau Shan Tuyet tea have been analysed on institutional influences of Gls on local products quality development and their supply chain management. The paper concludes with recommendations to promote Gl implementation in enhancing agricultural product quality in Vietnam

Research for this paper was funded by the Swiss State Secretariat for Economic Affairs under the SECO / WTI Academic Cooperation Project, based at the World Trade Institute of the University of Bern, Switzerland.

SECO working papers are preliminary documents posted on the WTI website (www.wti.org) and widely circulated to stimulate discussion and critical comment. These papers have not been formally edited. Citations should refer to a "SECO / WTI Academic Cooperation Project" paper with appropriate reference made to the author(s).

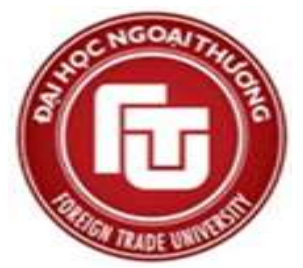




\title{
Geographical Indications and quality promotion of agricultural products in \\ Vietnam: an analysis of government roles
}

Thuy Nguyen, Giang Hoang, Kien Nguyen

\begin{abstract}
Geographical indications (GIs) play an important in the agriculture sector; however, the link between geographical indications and quality promotion has not been adequately analysed. This paper aims to investigate the influences of geographical indications on the quality of agricultural products in Vietnam, considering the role of public policies in this matter. We review the literature in GI protection in Vietnam, focusing on the role of the Government in structuring and implementing GIs and putting forward the institutional involvement. Three case studies on Phu Quoc fish sauce, Luc Ngan lychee and Moc Chau Shan Tuyet tea have been analysed on institutional influences of GIs on local products quality development and their supply chain management. The paper concludes with recommendations to promote GI implementation in enhancing agricultural product quality in Vietnam.
\end{abstract}

Key words: Geographical indications, agricultural product quality, government roles, Vietnam

\section{Backgrounds}

Agriculture plays a significant role in the economy of Vietnam. Before Doimoi (Renovation) in 1986, the policies focused on self-sufficiency in agriculture. After Doimoi, the focus was shifted to cash-crops, where crops became commercialised within Vietnam and were exported worldwide. This is proven by the fact that Vietnam has switched from a food insufficient nation to the world's second largest rice exporter in recent years. Some other prominent export goods such as coffee and pepper helped Vietnam earn a reputation as one of the largest agricultural product 
exporters in the world (Durand \& Fournier, 2015). In the past thirty years, the agricultural policies have been focusing on an aim to replace traditional techniques with the innovative ones. Whereas the initial focus was mainly on increasing productivity, it has recently expanded to improve food quality and safety (ESCAP 2009; Tran, 2014). These agricultural policies are first defined nationally by the Ministry of Agriculture and Rural Development, and more locally by provincial governments before being embedded into all other levels of government down the chain of command. With the current policy in agriculture, Geographical Indications (GIs) play as a tool to promote agricultural development. As defined in the next section, the governments play more important roles in GIs registration and development than local communities and local producers.

From the mid-1990s until recently, the Vietnamese Government has shown more concern to the development and application of GIs (Durand \& Fournier, 2015), and as a result, it is now seen as among the world's most active users of this policy tool (Benerji, 2012). GIs are not only cost effective but also a proficient way to combat the misappropriation of names in order to promote agricultural products abroad (Anders \& Caswell, 2009; Bramley \& Bienbee 2012; Vittori, 2010). The literature has primarily identified GIs as an effective agricultural policy tool (Durand \& Fournier, 2015). However, there is still lack of the literature on the influences of GI development to agricultural product quality in Vietnam. With the involvement of Vietnamese Government in the product selection, the implementation of GIs considered as well as the construction of Codes of Practices (CoP), they would be able to achieve this objective.

The Government can use GI policies to support producers in marketing their products better, at the same time legally protecting them from misuse or falsification of a product name in order to ensure the agricultural product quality. Despite many studies consensus on GIs, including the emerging but growing focus on the role of the governments in GI development, extremely few have examined the role of the governments in the governance of GI systems to promote agricultural product quality, 
and nearly none of them have analysed the contribution of local producers (Scudeller, 2009).

This paper aims to investigate the institutional role of governments, at both national and local level, in building and managing GIs. In addition, this study explores the level of interest and participation of local producers to GI development; and to analyse how GIs combined with agricultural policies are to improve agricultural product quality in Vietnam. Recommendations will be provided for governments and local producers to implement GIs system effectively as an agricultural policy tool in Vietnam.

In the following section we review the literature of GIs, the GI protection in Vietnam and role of the Government in designing and implementing GIs in Vietnam. Case studies will be mentioned in section 3 to exemplify the effects of GI on local stakeholders systems and strategies. Section 4 provides recommendations to Vietnamese Government regarding the GI implementation and strategy development in order to take full advantage of GIs and agricultural innovation for rural development, incomes and local identity.

\section{Literature Review}

\subsection{Geographical Indications (GIs)}

GIs are defined in many different ways. In this paper we work with the definition of the World Trade Organization (WTO) on Trade-Related Aspects of Intellectual Property Rights (TRIPS Agreement), article 22: “indications that identify a good as originating in the territory of a particular country, or a region or a locality in that country, where a given quality, reputation or other characteristic of the good is essentially attributable to its geographical origin" (WTO, 1994). Under the TRIPS Agreement, there are three major main conditions that a product has to satisfy to be recognised under the GI scheme: (1) it must relate to a specific type of agricultural or non-agricultural good (though in some countries services are also counted, including but not limited to Singapore, Croatia, Bahrain, Moldova, Jamaica; (2) these goods 
must originate from a defined area, and (3) that the goods must have qualities, reputations or other characteristics that are clearly linked to the geographical origin of goods (WTO, 1994; Kireeva \& O’Connor, 2010). Any products that are not able to meet these three conditions cannot be protected under GI terms of the TRIPS Agreement. The exact nature and extent of protection, however, are not specified in the agreement, and there is case law only for certain products.

As intellectual property rights (IPRs), GIs aim at protecting the origin and reputation of regional products, thus providing the protection against imitations in domestic and overseas markets (Akerlof, 1970). In many countries, GI protection is considered important in formulating general agricultural policy. With GIs, producer incomes may rise by collectively creating and strengthening product reputation, hence allowing a boost in local agricultural dynamics and growth in the local market (Bowen, 2010). This would then benefit other sectors of the local economy (Pecqueur et al., 2008). Especially where the initial steps of processing are required to take place in the same area, the economic benefits extend way beyond the local commodity producers. GIs could, therefore, be encouraged by governments to promote sustainable diversification in strategic agricultural production areas and help mitigate rural exodus.

Besides, GIs can empower local organisations and communities through the collective management needed to sustain the GI requirements, such as price of agricultural markets or resource conservation (Gangjee, 2012), by placing a higher premium on the local resources from which the product was sourced. This resource conservation can act to further enhance the autonomy of rural communities through 'grassroots economics' (Bowen, 2010). The production and management systems used to produce a given product are more likely to be influenced by GIs where the Codes of Practice determine whether an industrial process could be used for a certain product or not (Allaire \& Sylvaner, 1997). The case of Comté cheese in France is a typical example, because it is provided in the $\mathrm{CoP}$ of this GI, milk is not allowed to transported over more than $25 \mathrm{~km}$ before processing it, the processing units are mostly small-sized. A 
large unit is unable to collect enough milk amount to make itself profitable within a radius of $25 \mathrm{~km}$ (Durand \& Fournier, 2015).

More importantly, GIs may help to differentiate products of good quality from others, and better still, to change a product from pure "commodity" to that of an "origin product" (Galtier, Belltti \& Marescotti, 2013). This will lead to an increase of both the selling price and the market share of a product. Durand and Fournier (2015) suggest that the majority of consumers do respond to GI labelling, despite the fact that they are not overtly familiar with the geographical region the goods originated.

\subsection{Geographical Indications Protection in Vietnam}

Vietnam has only shown an interest in protecting GIs recently, not long after joining the WTO including the TRIPS Agreement in 2007. In 1998 by the success in building the first two appellations of origins (AO) products: Phu Quoc fish sauce and Shan Tuyet tea. By the end of 2005, the Intellectual Property Law, which included geographical indication, was approved by the Vietnam National Assembly. Even though Phu Quoc fish sauce and Shan Tuyet tea were not being protected in the market at the time of registration, these two products indeed flared up a movement for $\mathrm{AO}$ and GI across the country. Other provinces tried to build and register their own AO products which brought about the issues and difficulties in registration and protection of GI products afterwards. In the later sections, the paper would analyse the interventions of the Government in GI development in Vietnam, including its legal framework, the implementation and the distribution of tasks between central and local governments - and their impacts.

\section{A progressive establishment of legal frameworks}

In order to have a GI protection system, a corresponding legal framework was first set up in 1995 (Vu \& Dao, 2006). Since the TRIPS agreement on GIs did not specify the legal means needed to enact GIs, Vietnam had to decide on how it wanted to internally regulate and internationally protect their GI system on their own. 
From 1995 to 2005, a series of draft laws, decrees and Circulars was issued as a progress in constructing a regulatory framework related to GIs. Clear responsibility for different subjects involved in GIs was designated among various levels of government by laws. National experts and universities were entailed to ensure the drafts of the laws were in harmony with the Vietnamese and international legal background.

GIs and AOs terms were first protected under law for the decade from 1995 to 2005, under the Civil Code of 1995. The Ministry of Science, Technology and Environment, through the National Office for Industrial Property under decree 63/CP managed the scheme which defined AOs as well as their accreditation. During this period, only two AOs were recognised, a type of fish sauce and "snow tea" from Moc Chau. In 2007 when Vietnam prepared to join the World Trade Organisation, the IP regulations were revised. The reformed regulations (IP Law 2005, art. 79) granted the GI protection to any agro-food or handicraft product which would be attributable to one particular geographical region. The IP law was detailed, which made it clear and effective, and the GI registrations would be accelerated. Better still, geographical names can also be protected as certification trademarks.

\section{Beyond the Law: the diversification of the Government role in GI Development}

The Vietnamese Government's role has shifted far beyond simply maintaining a legal framework to support GIs. The Government promotes the development of GIs in different area: the training of national GI experts, and increasing the level of awareness of GIs at a local level; as well as financial support for GI implementation.

Besides, the government had maintained significant investment to the technical assistance area of GI, and a database of potential CoP Products. The whole production process is supervised under the public Authorities of Vietnam, and the partnership between the recognized research entities of Vietnam the Ministry of Science and Technology. 


\section{Government Participation in GI development: what authority at what level?}

In Vietnam, the decentralisation of power between the nation level and local level has raised many issues. According to Durand and Fournier (2015), there is not a clear delineation of responsibilities regarding GIs, and this leads to a messiness of administration. Theoretically, the ideal outcome is the cooperation and collaboration between local and central authorities, however it turns out that the powerfulness of the central administration outweighs any local collaboration efforts to some extent.

In the current GIs management system in Vietnam, there is delineation in authority between registering body which is central government exclusively, and the managing right is usually held by the local authority. A registered GI from the central government would then be delegated the management responsibility of that GI to a local branch of the Department of Science and Technology in the province. Although the processes seem relatively clear, what is less clear are the pre-registration phases when the provinces are over time more active in identifying potential local GIs and have put resources towards GI development, originally a domain held by the Central Administration. The shortcoming of this approach is that the provinces need federal funding and support to do so, however this support is not always forthcoming when the Central Government lacks either resources or the will to support those proposed GI projects.

The GIs post-registration phase appears to be more clearly outlined, regulated and delineated among different authority levels. Local public authorities often have the willingness to get involved but lack the internal resources to perform. In order to overcome this problem, some local authorities have sought to external support such as cooperation projects or private funding.

A successful GI registration and implementation process require cooperation between the central and the lower layers of governments, but the roles of each authority layer should be identified clearer. This is also the case in Europe according to Scudeller 
(2009). The case studies in Section 3 would give further illustration on the role of government and the influence on GI dynamics.

\section{Registered GIs in Vietnam}

Since 1995 Vietnam has registered 45 protected GIs (more details in Table 1), ranking it second among all ASEAN Countries, after Thailand (NOIP, 2016). These GIs is composed mainly of heritage agro-food and handicraft products: seventeen for fruits and vegetables, four types of spices, three aromatic rice varieties, three kinds of coffee, one handicraft product and eleven other products (NOIP, 2016).

Table 1: List of GIs for agricultural products and foodstuffs in Vietnam

\begin{tabular}{|c|c|c|c|c|c|}
\hline No. & $\begin{array}{c}\text { Name as } \\
\text { registered in } \\
\text { Vietnam }\end{array}$ & Description & No. & $\begin{array}{c}\text { Name as } \\
\text { registered in } \\
\text { Vietnam }\end{array}$ & Description \\
\hline 1 & Mộc Châu & Tea & 24 & Trà My & Cinnamon bark \\
\hline 2 & Buôn Ma Thuột & Coffee bean & 25 & Bình Thuận & Grape \\
\hline 3 & Đoan Hùng & $\begin{array}{c}\text { Grapefruit } \\
\text { (pomelo) }\end{array}$ & 26 & Tân Triều & $\begin{array}{c}\text { Grapefruit } \\
\text { (pomelo) }\end{array}$ \\
\hline 4 & Bình Thuận & Dragon fruit & 27 & Bảo Lâm & $\begin{array}{c}\text { Stoneless } \\
\text { persimmon }\end{array}$ \\
\hline 5 & Lạng Sơn & Star aniseed & 28 & Bắc Kạn & Tangerine \\
\hline 6 & Thanh Hà & Litchi & 29 & Yên Châu & Mango \\
\hline
\end{tabular}




\begin{tabular}{|c|c|c|c|c|c|}
\hline 7 & Phan Thiết & $\begin{array}{l}\text { Extract of } \\
\text { fish }\end{array}$ & 30 & Mèo Vạc & $\begin{array}{c}\text { Peppermint } \\
\text { honey }\end{array}$ \\
\hline 8 & Hải Hậu & Rice & 31 & Bình Minh & $\begin{array}{l}\text { Grapefruit } \\
\text { (pomelo) }\end{array}$ \\
\hline 9 & Vinh & Orange & 32 & Hạ Long & $\begin{array}{c}\text { Chopped } \\
\text { cuttlefish meat }\end{array}$ \\
\hline 10 & Tân Cương & Tea & 33 & Bạc Liêu & Salt \\
\hline 11 & Hồng Dân & Rice & 34 & Luận Văn & $\begin{array}{l}\text { Grapefruit } \\
\text { (pomelo) }\end{array}$ \\
\hline 12 & Lục Ngạn & Litchi & 35 & Yên Tử & $\begin{array}{l}\text { Apricot } \\
\text { blossom }\end{array}$ \\
\hline 13 & Hòa Lộc & Mango & 36 & Điện Biên & Rice \\
\hline 14 & Đại Hoàng & Banana & 37 & Quảng Ninh & Clam \\
\hline 15 & Văn Yên & $\begin{array}{l}\text { Cinnamon } \\
\text { bark }\end{array}$ & 38 & Vĩnh Kim & Star apple fruit \\
\hline 16 & Hậu Lộc & Shrimp paste & 39 & Cao Phong & Orange \\
\hline 17 & Bắc Kạn & $\begin{array}{l}\text { Stoneless } \\
\text { persimmon }\end{array}$ & 40 & Vân Đồn & $\begin{array}{l}\text { Sipunculus } \\
\text { nudus }\end{array}$ \\
\hline 18 & Phúc Trạch & $\begin{array}{l}\text { Grapefruit } \\
\text { (pomelo) }\end{array}$ & 41 & Đồng Giao & Pineaple \\
\hline 19 & Bảy Núi & Rice & 42 & Long Khánh & Rambutan \\
\hline
\end{tabular}




\begin{tabular}{|c|c|c|c|c|c|}
\hline 20 & Trùng Khánh & Chestnut & 43 & Ngọc Linh & Ginseng root \\
\hline 21 & Bà Đen & $\begin{array}{c}\text { Custard- } \\
\text { apple }\end{array}$ & 44 & Quảng Trị & Pepper \\
\hline 22 & Vĩnh Bảo & Pipe tobacco & 45 & Thường Xuân & Cinnamon bark \\
\hline 23 & Hà Giang & Orange & & & \\
\hline
\end{tabular}

Source: Adapted from Map of Geographical Indications of National Office of Industrial Property (NOIP) (2016)

Individual GI products' contribution to the national economy, or food security, varies. While almost all GIs play a part the provincial and local economy, some of these could bring symbolic and strategic value on a national level to Vietnam. Studies of Biénabe and Marie-Vivien (2015) and Jena and Grote (2010) shows that the Central Government also aims at GI to promote national heritage, by having the most extensive range of GI registered products presented in the ASEAN. Local governments well understand the significance of GI products and their participation in supporting and funding of GI enterprises would help ensuring that the Central Government keeps a focus on local priorities.

In short, although the establishment process are relatively long, but with the existence of steady legal frameworks, operational GI enterprises, and more importantly, the involvement of Vietnamese government, the number of applications has accelerated since its establishment. The central government's role in GIs is far beyond legal framework; they are the only group that can offer the correct support, given that the local economic actors often lack knowledge about GIs.

\subsection{Quality Promotion of Agricultural Products}

In this Section we review literature on agricultural products quality and discuss how the governments use their institutional roles to promote agricultural product quality. We also analyse the local production systems and supply chains that are generally 
applied in Vietnam to provide an overall picture of Vietnamese agricultural production and agricultural product quality promotion.

Intellectual property protection in general protects and stimulates creation and innovation in production and encourages healthy competition; and GI in particular protects a specific product attached to a locality which that have typical and specific quality based on its unique and geographical conditions (Civil law of the Socialist Republic of Vietnam in 1995).

Many food and agricultural products can be categorized into "credence" goods where only producers know what they are selling and consumers could only know the characteristics of products once they are consumed (Anania \& Nisticò, 2004). GIs can be an effective way to promote agricultural products in a context of globalisation by reducing the risk of misappropriation of names (Bramley \& Biénabe, 2012) and avoiding the situations as "bad products drive out good ones" (Durand \& Fournier, 2015). Therefore, institutional role in labelling product quality and quality promotion of agricultural products is prominent. Besides establishing the legal framework that includes compulsory technical rules for the supply chain in order maintain the GIs' products specific quality, there are also researchers from national institutes that have expertise in rural and agricultural development to take charge of quality verification and promotion. In the modernisation effort of Vietnamese authority in identifying the best Codes of Practices, Durand \& Biénabe (2015) concluded that there are mixed results in the effectiveness of modernized methods applied to traditional know-hows, much depending on the reaction and cooperation of the local producers.

Moreover, the supply and demand for agro-product can highly fluctuate by several factors, such as weather, temperature and customer preferences (Chen, Li \& Jin, 2015). The occurrence of these uncertain factors may twist the agricultural supply chain with wrong decisions made upon the previous year's demand anticipation.

In Vietnamese domestic market, self-sufficiency in food production has been achieved in terms of volume, but not in terms of food safety and quality. According to a report 
of the Ministry of Trade (2004) Vietnam has implemented a protection policy for some processed farm products and foodstuffs by imposing import tariffs of up to 50\% on some kinds of processed vegetables, fruit and meat, and $40 \%$ on fruit (Université de Montreal, 2008). Recently, after joining the WTO, Vietnam has committed to slash import tariffs on farm products resulting in fiercer competition for domestic farm products on domestic markets (but with an incentive for higher productivity and hence better competitiveness for exports). The country has to invest further in improving agricultural productivity and quality, provide assistance to help the farming sector expand to reach overseas markets and provide training to farmers, because only $15 \%$ of the agricultural labour force is skilled (Université de Montreal, 2008). The agricultural sector should also upgrade its production and processing equipment to help produce high-quality agricultural products and endeavour to respect international standards on quality and sanitation to protect their domestic market and to make inroads into export markets (Université de Montreal, 2008). For the above reasons, the Government of Vietnam is trying to move the agriculture from a quantity/volume oriented production to quality, sufficiency and sustainability. Since the issue has been raised, GIs is considered as a policy tool to help improve agricultural product quality.

\section{Case studies}

In this section we analyse three case studies of geographical indications, which are Phu Quoc fish sauce, Luc Ngan lychee, and Moc Chau Shan Tuyet tea. Each case study describes the sequence of the product before and during registration. The GI building process and quality development of these products are analysed in order to see both the CoPs guidance to production systems toward quality promotion and how institutional roles of local and central governments contribute to the development of GIs and promotion of agricultural products quality.

\subsection{Phu Quoc fish sauce}

Phu Quoc Island in Kien Giang province is a famous fish sauce hub in Vietnam. Phu Quoc fish sauce has long been famous for its delicious flavour which is characterized 
by the raw anchovies and the traditional method in the production process. With its distinctive features, Phu Quoc fish sauce is the first Vietnam fishery product registered for appellation of origin.

The main characteristics of the sauce is that it is only made on this Phu Quoc Island in Vietnam, made exclusively from anchovies in surrounding waters, and then fermented at high temperatures. It has a less fishy taste than some other fish sauces, the initial flavour is salty, and it then has a sweet aftertaste. The sauce is a dark reddish brown colour. The production of the sauce of course begins with the anchovies which feed on the abundant seaweed and plankton that surrounds the island. Traditional tunny nets are used to catch the fish, which are then cleaned, salted and stored covered in the boat's hold. The fish are then barrelled and left to ferment for 12-15 months, once fermented the sauce is bottled on the island and it's ready for sale. More information about Phu Quoc fish sauce is presented in Table 2.

Table 2: Information about Phu Quoc fish sauce

\begin{tabular}{|l|l|}
\hline \multicolumn{1}{|c|}{ Type of product } & \multicolumn{1}{c|}{ Fish sauce (fish extract) } \\
\hline Control body & Phu Quoc Fish Sauce Control Board \\
\hline Competent authority & National Office of Intellectual Property (Vietnam) \\
\hline Date of registration & $11 / 05 / 2001$ \\
\hline Geographical area & $\begin{array}{l}\text { Phu Quoc Island, the biggest island in Vietnam, is located } \\
\text { in the Vietnamese territorial waters of the gulf of } \\
\text { Thailand. }\end{array}$ \\
\hline $\begin{array}{l}\text { Link between product } \\
\text { and territory }\end{array}$ & $\begin{array}{l}\text { The sauce is produced using local anchovies, combined } \\
\text { with processing by local traditional knowledge. }\end{array}$ \\
\hline
\end{tabular}


Souce: NOIP (2016)

However, ever since the fish sauce product was registered by the NOIP dated in 01/06/2001, there were limited supporting activities. There are countless floating counterfeit goods of Phu Quoc fish sauce in the consumer market and the quality of fish sauce is not strictly controlled. The difficulty for the producer of Phu Quoc fish sauce is even more overwhelming when the anchovy is depleting and the price of electricity, water and labour costs are also increasing, while the selling price remains unchanged.

Under this situation, in order to create a legal foundation to assert Phu Quoc fish sauce brand, in October 2008 the People's Committee of Kien Giang province has issued Decision 2482 to regulate the management and use of GIs of Phu Quoc fish sauce product; Decision No. 201 of the People's Committee of Phu Quoc district has established the Supervisory Board for Phu Quoc fish sauce and Decision No. 2855 of Phu Quoc District People's Committee dated 16/08/2010 on the issuance of a temporary regulation on the control of GI of Phu Quoc fish sauce. Until recently, 65 business production/ enterprises producing fish sauce in Phu Quoc Island has been permitted to use the GI by the Department of Science and Technology in Kien Giang Province.

In addition, after the decision issued by the province and district, Phu Quoc Fish Sauce Association has also released regulations on internal control and established an Internal Control Committee. This Committee is responsible for examining, controlling and applying the existing state regulations on GI for fish sauce products. By the year 2014, the Association has 93 business production members. However, only 15 enterprises among which committed to implement GIs activities such as code barrel registration, and data recording for each barrel soaking process. There are 8 
enterprises that already registered for a GI trademark and are ready to launch their first protected product to the market.

GI of Phu Quoc fish sauce has also specified details for the anchovy area, ingredients, the ratio of other fish (other than anchovies) at fewer than $15 \%$, the instrument and instrument material, processing methods, requirements in terms of quality, labelling, food safety, and preservation techniques. However, the deployment and operation in practice still incur many limitations, the terms are difficult to implement in the controlling process as well as in actual practice of the producers. The Supervisory Board of fish sauce did not have a smooth operation; therefore, the deployment of the application of the provisions on GIs for Phu Quoc fish sauce has not achieved the desired effect. To solve the problems, the Rural Development Centre - Institute of Policy and Strategy for Agriculture and Rural Development has been developing a set of activities in managing and consulting the use of GI for Phu Quoc fish sauce products. For example, GIs management models have been developed in order to implement operational regulations control in practice and provide training and promoting the usage of GIs for Phu Quoc fish sauce.

\subsection{Luc Ngan lychee (or litchi)}

Most of the Lychee production in North Vietnam occurs in the mountainous region, on the north of the red river. This study focused on production in the Luc Ngan district a 1012 square $\mathrm{km}$ area in Bac Giang (located about eighty kilometres northeast of Hanoi), as this is a prominent centre for lychee production. The Luc Ngan district is home to " 173,000 people living in 31,000 households" with annual rainfall of 1800$2000 \mathrm{~mm}$ per year and average annual temperature between 18 and 23 degrees Celsius, as well as a lack of regular storm events, the climate and landscape of the district are well suited to lychee production, the majority off the land in this area is not suited to field crops, only orchards. More information about Luc Ngan lychee is presented in Table 3.

Table 3: Information about Luc Ngan lychee 


\begin{tabular}{|c|c|}
\hline Type of product & Fruit \\
\hline Date of Registration & $25 / 06 / 2008$ \\
\hline Geographical area & $\begin{array}{l}\text { Production of these lychees is carried out in the following } \\
\text { areas. Chu town and Dong Coca, Bien Son, Bien Dong, Giap } \\
\text { Son, Hong Giang, Kien Lao, Kien Thanh, My An, Nam } \\
\text { Duong, Nghia Ho, Phi Dien, Phuong Son, Quy Son, Tan Hoa, } \\
\text { Tan Lap, Tan Moc, Tan Quang, Thanh Hai and Tru Huu } \\
\text { communes in the district of Luc Ngan, Bac Giang province. }\end{array}$ \\
\hline Competent authority & National Office of Intellectual Property of Vietnam \\
\hline $\begin{array}{l}\text { GI right holder/GI } \\
\text { association }\end{array}$ & Department of Science and Technology, Bac Giang province \\
\hline $\begin{array}{l}\text { Main Characteristics } \\
\text { and Features }\end{array}$ & $\begin{array}{l}\text { Luc Ngan lychees weigh between } 20.5-24.2 \text { grams. Width is } \\
\text { typically between } 3.25-3.58 \mathrm{~cm} \text {, and height is typically } \\
\text { between } 3.16-3.46 \mathrm{~cm} \text {. when ripe the peel is smooth and the } \\
\text { frit large and spherical. }\end{array}$ \\
\hline $\begin{array}{l}\text { Production and } \\
\text { processing }\end{array}$ & $\begin{array}{l}\text { These lychees are best planted during the months of February } \\
\text { and March, spring in Vietnam, due to the following autumn } \\
\text { weather pattern. The trees are planted with five by five meter } \\
\text { spacing, or a density of between } 280-350 \text { trees per hectare. } \\
\text { The soil selecting and planting particulars are that they are } \\
\text { usually planted in wide holes, with a mix of light soil and } \\
\text { sand. If Ferrosols the same procedure is followed but soil bags } \\
\text { are placed about } 7-10 \mathrm{~cm} \text { below the surface. }\end{array}$ \\
\hline
\end{tabular}


Link between product and territory
The climate and soil of the area contribute to the quality and uniqueness of the Luc Ngan lychee. There are numerous micronutrients that acts to develop fruits of an exceptional quality, for example calcium can increase the weight and guilty of fruits. Micronutrients found in ferrosol soil include calcium, iron, zinc, boron, molybdenum. It is common practice in the area to thoroughly prune the plant post the harvest period.

Souce: NOIP (2016)

The local authorities in Bac Giang province has identified GI as an important and long-term legal foundation which contributes to the innovation of production, cumulative value and branding development for Luc Ngan lychee. The province leaders also aware that GIs development as a strategy to effectively coordinate all stages of production such as breeding and caring techniques, use of fertilizers, pest control and postharvest preservation. In 2004, the People's Committee of Bac Giang province approved the project, namely "Branding for the specialty products of Bac Giang province in 2005-2010", in which Luc Ngan lychee was considered the most important product. Also in that year, the Department of Science and Technology of Bac Giang province supported the Gardening Association of Luc Ngan district to develop a collective branding of "Luc Ngan Lychee" which was then certified by the National Office of Industrial Property (NOIP) with the registration number 62801 (by decision No. 4930/QD-DK, dated $17^{\text {th }}$ May 2005). On $25^{\text {th }}$ June 2008, the Director of the NOIP issued GI registration certificate No. 00015 for Luc Ngan lychee. The establishment of GIs protection for Luc Ngan lychees has significant impacts on the production and the brand development of the product. First, it affirms the origin of the product, indicates the nature and quality characteristics of lychee grown in Luc Ngan, and distinguishes Luc Ngan lychee from other types of lychee grown in other regions. 
Furthermore, this is also an opportunity to promote the development of other economic sectors such as the processing industry and ecological tourism.

Recently, Bac Giang province has mobilized resources and solutions to improve productivity and quality, as well as expanded consumption market for lychee. This manifests itself through a number of action plans, such as Dispatch 889-CV/TU dated 16/9/2014 of Bac Giang Provincial Party Committee, which instructed all related government agencies, departments and ministries to coordinate for export promotion plan for Luc Ngan lychee into Japan and US market. The provincial People's Committee has issued "Plan 3110/KH-UBND dated 28/10/2014 on export promotion of lychee in 2015 and in the following years" and Decision 1863/QĐ-UBND dated 14/11/2014 of provincial People's Committee on the establishment of the Steering Committee for agricultural production and export of Bac Giang province for the period from 2014 to 2016. Growing (and locally processing?) lychee has created rural jobs for thousands of employees, thereby limiting the migration from the rural areas and contributes to preserve the identity, environment, landscape, biodiversity in rural areas. For Luc Ngan district, since lychee has been announced as a GI, the revenue from this crop has increased rapidly over the years despite the reduction of growing area. In 2007, the revenue was VND 500 billion, and in 2015 the number had over tripled to VND 1,770 billion. In 2015, the total revenue from lychee production and other ancillary services of the province was VND 4,600 billion, as a result of penetration into high quality demanding markets such as US, Australia, Britain, France, and Japan.

\subsection{Moc Chau Shan Tuyet tea}

Along with Phu Quoc fish sauce, Moc Chau Shan Tuyet tea was also the first to be GI registered in Vietnam. Moc Chau Shan Tuyet tea is specially grown in the northwestern highland of Son La province, at the height of $1050 \mathrm{~m}$ over the sea level, with the annual temperature at $18.5^{\circ} \mathrm{C}$. Shan Tuyet tea was first cultivated and enlarged 
during the period from 1958 to 1965 when Moc Chau plantation was established. More information about Luc Ngan lychee is presented in Table 4.

Table 4: Information about Moc Chau Shan Tuyet tea

\begin{tabular}{|c|c|}
\hline Type of product & Tea \\
\hline Main characteristics & $\begin{array}{l}\text { Shan Tuyet Moc Chau tea covers two types of tea with } \\
\text { the following features: - black tea - black-brown colour, } \\
\text { strong typical aroma and sweet taste; - green tea - black- } \\
\text { green colour, strong typical aroma and sweet taste } \\
\text { (neither astringent, nor bitter). }\end{array}$ \\
\hline Competent authority & National Office of Intellectual Property (Vietnam) \\
\hline Date of registration & 09/08/2010 \\
\hline Geographical area & $\begin{array}{l}\text { The Moc Chau tea production area is located in } 17 \\
\text { communes/townships (Van Ho, Suoi Bang, Quy Huong, } \\
\text { Long Sap, Chieng Son, Chieng Khoa, Muong Sang, Tan } \\
\text { Lap, To Mua, Chieng Yen, Dong Sang, Chieng Khua, } \\
\text { Phieng Luong, Chieng Hac, Long Luong, Moc Chau, Moc } \\
\text { Chau Farm) of the Moc Chau district, Son La province, in } \\
\text { Vietnam }\end{array}$ \\
\hline $\begin{array}{l}\text { Link between product and } \\
\text { territory }\end{array}$ & $\begin{array}{l}\text { A typical tea variety in Moc Chau is Shan Tuyet, due to } \\
\text { the climate, soil, and other geographical conditions that } \\
\text { contribute to making this tea distinctive with a very } \\
\text { special aroma. It is very different from tea that originates } \\
\text { from other areas }\end{array}$ \\
\hline
\end{tabular}


GI right holder

Department of Science and Technology of Son La Province

Souce: NOIP (2016)

In 2001, Shan Tuyet Moc Chau tea was registered by Moc Chau Tea Company to protect two types of Moc Chau tea: green tea and black tea. There are two main organisations that run the tea production in Moc Chau, which are Moc Chau Tea Company under Vietnam Tea Corporation and Co Do plantation. However, appellation of origin was only registered for Moc Chau Tea Company and protected throughout Vietnam. Although having registered, Shan Tuyet tea has not actually been protected as an appellation of origin due to two reasons (Vu \& Dao, 2010). First, there is lack of a system for quality management which is crucial in defining the quality of the product and differentiate the origin. Second, Moc Chau Tea Company refused to implement the quality controlling system that was financially sponsored by the Ministry of Agriculture and Rural Development with an explanation the quality control system would raise production cost which would affect its stable market. Furthermore, Moc Chau Tea Company did not apply any strategy to clarify the sign of appellation of origin in their product labels.

There needed different management bodies to involve in the process of registering and protecting the product under appellation of origin, which includes the Ministry of Agriculture and Rural Development, the Department of Intellectual Property, the Tea Association, Vietnam Tea Corporation, and the applicant which was Moc Chau Tea Company.

The Ministry of Agriculture and Rural Development is controlling body for both production and business activities in the tea product. However, there is no competent body in charge of protecting appellation of origin and geographical indication, so this was assigned to the Department of Science and Technology as an additional role. The fact that the Department is short of staff has limited their performance in receiving and 
managing application document for appellation of origin and geographical indication in a timely manner. There is also an unclear division of responsibility in conducting scientific investigation in the production procedure and quality control system between the Ministry of Agriculture and Rural Development and the Ministry of Science and Technology. This explains why even though Moc Chau Shan Tuyet tea was registered as an appellation of origin but the tea product was not effectively protected.

\section{Recommendations and policy implications}

There is a significant diversity amongst the cases studies; a reflection upon the whole of Vietnam's registered GIs. The reputation of products before they became registered GIs varies, the markets the products were targeted at varies. There are some features of GI development that are constant, this includes most notably that there is always a heavy involvement by the Government of Vietnam. The Government of Vietnam's involvement can be explained by the potential impacts GIs could have on the Vietnamese economy, and Vietnamese agricultural policy. The government of Vietnam makes use of GIs to avoid counterfeiting internationally, such as was commonly the case with Phu Quoc fish sauce, but more commonly GIs have been aimed at creating a differentiation between products of Vietnam and other competitors helping to increase its export value, in turn assisting the economy of Vietnam, and its food reputation abroad. The Government of Vietnam provides the resources for GI implementation, choosing to dedicate those resources to the projects which will produce the best agricultural development, at the expense of some other projects of less national value, across all regions.

In this Section, we provide policy implications for Vietnamese Government in improving GI protections and recommendations for local producers to develop their strategies in order to take full advantage of GIs and quality promotion of agricultural products.

\subsection{Improving the legal frame on geographical indication}


According to $\mathrm{Vu} \& \mathrm{Dao}$ (2006), the application of GI in Vietnam remains many difficulties due to imperfect legal system. Therefore, it is vital to improve policies in GI management in order to enhance products quality and the competitiveness of Vietnamese agricultural products in the overseas markets.

We recommend the Government to strictly apply the regulations of WTO on intellectual property. It is vital to apply the law of Intellectual Property strictly since it will form the legal frame for the GI procedure in Vietnam. However, it is necessary to provide supplementary regulations during the application, for example, establishing a general GI management system for all products under the control of a specific competent organization or giving the rules for property, management of rights as the right of use by defining the roles of organizations representing the State, local government, and ministries and the rights and obligations of the users. It is also necessary to ensure the rights and obligations of the local producers when establishing a general GI management system.

The government authority, based on the registration requests by the users, should describe the procedure of preparing documents and steps necessary to establish the right to GI products, stipulating methodologies of delineation, quality description, and particular production process with the justifications and confirmation of competent organizations (management or science organizations, central or local).

The Government should clearly define the roles and responsibilities of the state, competent organizations as ministries, market management organizations, local government, and other organizations and individual in GI development. All the rules of traditional production process, control system, and the description of production situation and market should be verified by competent/independent organizations.

\subsection{Improving quality management system related to GI products}


Policies should be issued to support the development of GI products. In addition it is necessary to launch national strategies to preserve and commercialize these products and to improve their quality and competitiveness in domestic and oversea markets.

In order to support for these strategies, the Government should build internal and external control systems to enhance the role of producer organizations, for instance the Association of Phu Quoc fish sauce producers, the Association of Moc Chau tea producers and the Luc Ngan Lychee Consumption and Production Association.

Moreover, the Government should get involved in improving organization of producers, commodity chain of GI products to some extend to ensure the quality of the GI production system. To achieve this goal, it is important to improve and raise the role of the associations, and raise the participation of the local authority; as well as define the function of these associations in production management and product commercialization.

In order to develop a material system for a closed chain including producing, processing, packaging, and distributing, it is vital to have the support of the government and all stakeholders of commodity chain, then improving the ability of small producers ( $\mathrm{Vu} \& \mathrm{Dao}, 2006)$. Furthermore, it is necessary to have a control system of hygiene and safety for all GI products. The forms of food quality and safety management are encourage to apply into GI system, for example HACCP, GAP, GLOBLGAP and international quality management companies should be linked together to form effective systems of product quality management.

The Government should raise the awareness of geographical indication and its benefits for producers and all stakeholders of the production so that they are aware of their responsibilities, rights and their tasks in improving product quality. 


\section{Conclusion}

This paper attempts to explore the relationship between GIs protection and agricultural product quality development in Vietnam, considering the role of public policies in this matter. The literature and our policy review have shown that the Government of Vietnam made significant progress in GI protection and implementation. Thanks to GI protection, many products have found more markets both domestic and overseas, for example Cao Phong orange, Luc Ngan lychee, and Binh Thuan dragon fruit. However, three case studies on Phu Quoc fish sauce, Luc Ngan lychee and Moc Chau Shan Tuyet tea establish that the Government at both central and local level has not been effectively using GI as a policy tool to help improve products quality development and supply chain management. The study provides several recommendations for the Government in order to better use GIs as a policy tool in enhancing agricultural product quality in Vietnam. 


\section{References}

Akerlof, G. A. (1970). The market for "Lemons": Quality uncertainty and the market mechanism. Quarterly Journal of Economics, 84(3), 488-500.

Allaire, G., \& Sylvander, B. (1997). Qualité spécifique et innovation territoriale. Cahiers d'Economie et de Sociologie Rurales, 44, 29-59.

Anania G. and R. Nisticò (2004) "Public Regulation as a Substitute for Trust in Quality Food Markets: What if the trust substitute cannot be fully trusted?" Journal of Institutional and Theoretical Economics 160:681-701.

Anders, S., \& Caswell, J. A. (2009). The benefits and costs of proliferation of geographical labelling for developing countries. Estey Centre Journal of International Law and Trade Policy, 10(1), 77-93.

Berard, L., \& Marchenay, P. (2004). Les produits de terroir - Entre culture et re 'glements. Paris: CNRS E’ ditions.

Benerji, M. (2012). Geographical indications: Which way should ASEAN go?. Boston College Intellectual Property \& Technology Forum, 1, 8, <http://bciptf.org/wpcontent/uploads/2012/06/Geographical_Indications.pdf>

Biénabe, E., \& Marie-Vivien, D. (2015). Institutionalizing geographical indications in southern countries: Lessons learned from Basmati and Rooibos. World Development, <http://www.sciencedirect.com/science/article/pii/S0305750X15000881>

Bowen, S. (2010). Embedding local places in global spaces: Geographical indications as a territorial development strategy. Rural Sociology, 75(2), 209-243.

Bowen, S., \& Zapata, A. V. (2009). Geographical indications, terroir, and socioeconomic and ecological sustainability: The case of tequila. Journal of Rural Studies, 25(1), 108-119. 
Bramley, C., \& Bie'nabe, E. (2012). Developments and considerations around geographical indications in the developing world. Queen Mary Journal of Intellectual Property, 2(1), 14-37.

Chen, W., Li, J., \& Jin, X. (2016). The replenishment policy of agri-products with stochastic demand in integrated agricultural supply chains. Expert Systems with Applications: An International Journal, 48 (C), 55-66

Durand, C., \& Fournier, S. (2015). Can Geographical Indications Modernize Indonesian and Vietnamese Agriculture? Analyzing the Role of National and Local Governments and Producers' Strategies, World Development (2015), http://dx.doi.org/10.1016/j.worlddev.2015.11.022

ESCAP (2009). Sustainable agriculture and food security in Asia and the pacific, economic and social commission for Asia and the pacific. Bangkok: United Nations.

Galtier, F., Belletti, G., \& Marescotti, A. (2013). Factors constraining building effective and fair geographical indications for coffee: Insights from a Dominican case study. Development Policy Review, 31, 597-615.

Gangjee, D. S. (2012). Geographical indications and cultural heritage. WIPO Journal, 4, 92-102.

Jena, P. R., \& Grote, U. (2010). Changing institutions to protect regional heritage: A case for geographical indications in the Indian agrifood sector. Development Policy Review, 28(2), 217-236.

Kireeva, I. \& O'Connor, B. (2010). Geographical Indications and the TRIPS Agreement: What Protection is Provided to Geographical Indications in WTO Members?, The Journal of World Intellectual Property, 13( 2), 275-303.

Law on Intellectual Property (2005). Link online, http://www.noip.gov.vn/noip/resource.nsf/vwResourceList/6A7273451828D79C 
472576720020482D/\$FILE/Intelletual\%20Property\%20Law\%20of\%20Viet\%20 Nam\%202005.pdf

National Office of Industrial Property (NOIP) (2016). Maps of Geographical Indications in Vietnam, Link online: http://noip.gov.vn/web/noip/home/vn?proxyUrl=/NOIP/RESOURCE.NSF/vwRe sourceList/A0DC504F9D155F324725776D0026E5A0/\$FILE/index_vn.html

Pecqueur, B., Hirczak, M., Moalla, M., Mollard, A., Rambolinaza, T., \& Vollet, D. (2008). From the basket of goods to a more general model of territorialized complex goods: Concepts, analysis grid and questions. Canadian Journal of Regional Science, 31(2), 241-259.

Scudeller, A. (2009). Les produits sous indications ge'ographiques. Avantages et inconve'nients pour les producteurs; le ro^ le des institutions re'gionales et locales. In Y. Tekelioglu, H. Ilbert, \& S. Tozanli (Eds.), Les produits de terroir, les indications géographiques et le de'veloppement local durable des pays me'diterrane'ens, Options Me'diterrane 'ennes: $\mathrm{Se}^{\prime}$ rie A. Se'minaires Me'diterrane'ens (pp. 67-71). Montpellier: CIHEAM.

Tran, C. T. (2014). Overview of agricultural policies in Vietnam. FFTC Agricultural Policy Platform (FFTC-AP). <http://ap.fftc.agnet.org/ap_db.php?id=195>

Université de Montréal (2008). Food Agricultural Products Quality Development and Control Project (FAPQDCP), Retrieved from http://www.medvet.umontreal.ca/fapqdcp/files/FAPQDCP_Project\%20Impleme ntation\%20Plan.pdf

Vittori, M. (2010). The international debate on geographical indications (GIs): The point of view of the global coalition of GI producers. Journal of World Intellectual Property, 13(2), 304-314. 
Vu, T. B., \& Dao, D. H. (2006). Geographical indication and appellation of origin in Vietnam: Reality, policy, and perspective. Hanoi: Institute of Policy and Strategy for Agricultural and Rural Development.

World Trade Organisation (WTO) (1994). Agreement on Trade-Related Aspects of Intellectual Property Rights (TRIPS Agreement) 